\title{
Zespół kruchości w gabinecie lekarza praktyka - o czym należy pamiętać?
}

\section{Frailty syndrome in clinical practice - what should we remember?}

\author{
Paweł Łęgosz ${ }^{1}$, Bartosz Krzowski², Anna E. Płatek ${ }^{2,3}$, Anna Ryś ${ }^{2}$, \\ Karolina Semczuk-Kaczmarek ${ }^{2}$, Filip M. Szymański ${ }^{2}$, Paweł Małdyk ${ }^{1}$ \\ ${ }^{1}$ Katedra i Klinika Ortopedii i Traumatologii Narządu Ruchu Warszawskiego Uniwersytetu Medycznego \\ ${ }^{2}$ I Katedra i Klinika Kardiologii Warszawskiego Uniwersytetu Medycznego \\ ${ }^{3}$ Katedra i Zakład Patologii Ogólnej i Doświadczalnej Warszawskiego Uniwersytetu Medycznego
}

\section{Streszczenie}

Nie u wszystkich pacjentów proces starzenia się przebiega w ten sam sposób. Tempo postępowania tego procesu, zarówno fizycznego, jak i psychicznego, jest bardzo różne. Jakość życia pacjenta w podeszłym wieku zależy od bardzo wielu czynników, w tym stylu życia, predyspozycji genetycznych oraz odpowiedniej opieki medycznej. Jakość opieki zdrowotnej zależy między innymi od tego, jak szybko i czy prawidłowo lekarz dostrzeże u pacjenta oznaki przedwczesnego, czy "nieprawidłowego" starzenia się. Aby to ułatwić, wyodrębniono zespół objawów, których występowanie powinno zaalarmować lekarza ze względu na związek ze zwiększoną śmiertelnością. W piśmiennictwie anglojęzycznym zespół ten nosi nazwę frailty syndrome. W piśmiennictwie polskim najszerzej używane określenie tego zjawiska to prawdopodobnie „zespół kruchości”. Celem niniejszego opracowania było przedstawienie znaczenia tego zespołu w praktyce klinicznej.

Słowa kluczowe: starzenie się, zespół kruchości, podeszły wiek

Folia Cardiologica 2018; 13, 2: 137-143

\section{Wstęp}

W ostatnich latach obserwuje się starzenie się polskiego społeczeństwa. Według prognoz Głównego Urzędu Statystycznego tendencja zwiększania się liczby ludności w podeszłym wieku będzie się utrzymywać do 2050 roku [1]. Lekarze praktycy zdają sobie doskonale sprawę z tego, że nie u wszystkich pacjentów proces starzenia przebiega w ten sam sposób. Tempo postępowania procesu starzenia się, zarówno fizycznego, jak i psychicznego, jest bardzo różne. Jakość życia pacjenta w podeszłym wieku zależy od bardzo wielu czynników, w tym stylu życia pacjenta, predyspozycji genetycznych oraz odpowiedniej opieki medycznej. Jakość opieki zdrowotnej zależy między innymi od tego, jak szybko i czy prawidłowo lekarz dostrzeże u pacjenta oznaki przedwczesnego, czy „nieprawidłowego” starzenia się. 0 ile każdego lekarza zaniepokoi wystąpienie zawału serca czy udaru mózgu, o tyle zmniejszona prędkość chodu rzadko jest uznawana za niepokojący objaw. A warto również zwracać uwagę na ten i inne mniej oczywiste objawy, które wpływają na złe rokowanie pacjenta i podejmować kroki w celu ich eliminacji. Aby to ułatwić, wyodrębniono zespół objawów, których występowanie powinno zaalarmować lekarza ze względu na związek ze zwiększoną śmiertelnością. W piśmiennictwie anglojęzycznym zespół ten nosi nazwę zespołu kruchości (FS, frailty syndrome). W piśmiennictwie polskim spotyka się różne tłumaczenia, jednak najszerzej używane to prawdopodobnie „zespół kruchości”. 
Tabela 1. Kryteria rozpoznania zespołu kruchości

\begin{tabular}{|c|c|c|}
\hline Kryteria & Definicja CHS & Definicja WHAS \\
\hline \multirow{4}{*}{$\begin{array}{l}\text { 1. Utrata masy } \\
\text { ciała }\end{array}$} & Wyjściowo & Wyjściowo \\
\hline & $\begin{array}{l}\text { Niezamierzona utrata > } 10 \text { funtów* masy ciała } \\
\text { w ostatnim roku }\end{array}$ & 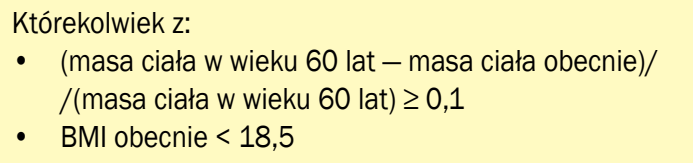 \\
\hline & Podczas follow-up & Podczas follow-up \\
\hline & $\begin{array}{l}\text { (Masa ciała w poprzednim roku - masa ciała } \\
\text { obecna)/(masa ciała w poprzednim roku) } \geq 0,05 \\
\text { oraz niezamierzona utrata masy ciała }\end{array}$ & 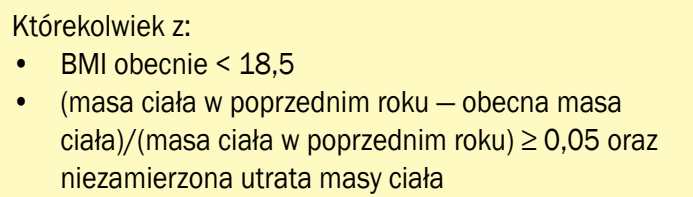 \\
\hline 2. Utrata energii & $\begin{array}{l}\text { Podawane przez pacjenta: } \\
\text { - } \quad \text { uczucie, że wszystko co zrobił w czasie ostat- } \\
\text { niego tygodnia łączyło się z wysiłkiem } \\
\text { - } \quad \text { brak możliwości zmuszenia się do wykonywa- } \\
\text { nia czynności w ostatnim tygodniu }\end{array}$ & $\begin{array}{l}\text { Podawane przez pacjenta: } \\
\text { - } \quad \text { zwykle niska energia ( } \leq 3 \text { w skali 0-10) } \\
\text { - w czasie ostatniego miesiąca przeważnie odczuwane } \\
\text { zmęczenie } \\
\text { - w czasie ostatniego miesiąca przeważnie odczuwane } \\
\text { osłabienie }\end{array}$ \\
\hline \multirow[t]{2}{*}{$\begin{array}{l}\text { 3. Niska aktyw- } \\
\text { ność fizyczna }\end{array}$} & $\begin{array}{l}\text { Kobiety: < } 270 \text { kcal w skali aktywności } \\
\text { (18-elementowa skala) }\end{array}$ & $\begin{array}{l}\text { Kobiety: < } 90 \text { kcal w skali aktywności } \\
\text { (6-elementowa skala) }\end{array}$ \\
\hline & $\begin{array}{l}\text { Mężczyźni: < } 383 \text { kcal w skali aktywności } \\
\text { (18-elementowa skala) }\end{array}$ & $\begin{array}{l}\text { Mężczyźni: < } 128 \text { kcal w skali aktywności } \\
\text { (6-elementowa skala) }\end{array}$ \\
\hline \multirow[t]{3}{*}{ 4. Spowolnienie } & Przejście 15 stóp (4,57 m) zwykłym tempem & Przejście 4 m zwykłym tempem \\
\hline & $\begin{array}{l}\text { Kobiety: } \\
\text { - } \quad \text { czas } \geq 7 \text { s dla wzrostu } \leq 159 \mathrm{~cm} \\
\text { - } \quad \text { czas } \geq 6 \text { s dla wzrostu }>159 \mathrm{~cm}\end{array}$ & $\begin{array}{l}\text { Kobiety: } \\
\text { - } \quad \text { prędkość } \leq 4,57 / 7 \mathrm{~m} / \mathrm{s} \text { dla wzrostu } \leq 159 \mathrm{~cm} \\
\text { - } \quad \text { prędkość } \leq 4,57 / 6 \mathrm{~m} / \mathrm{s} \text { dla wzrostu }>159 \mathrm{~cm}\end{array}$ \\
\hline & $\begin{array}{l}\text { Mężczyźni: } \\
\text { - } \quad \text { czas } \geq 7 \text { s dla wzrostu } \leq 173 \mathrm{~cm} \\
\text { - } \quad \text { czas } \geq 6 \text { s dla wzrostu }>173 \mathrm{~cm}\end{array}$ & $\begin{array}{l}\text { Mężczyźni: } \\
\text { - } \quad \text { prędkość } \leq 4,57 / 7 \mathrm{~m} / \mathrm{s} \text { dla wzrostu } \leq 173 \mathrm{~cm} \\
\text { - } \quad \text { prędkość } \leq 4,57 / 6 \mathrm{~m} / \mathrm{s} \text { dla wzrostu }>173 \mathrm{~cm}\end{array}$ \\
\hline \multirow[t]{3}{*}{ 5. Osłabienie } & Siła uchwytu & Siła uchwytu \\
\hline & 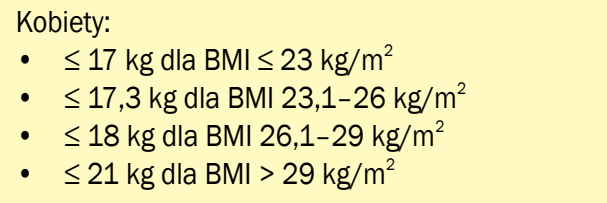 & 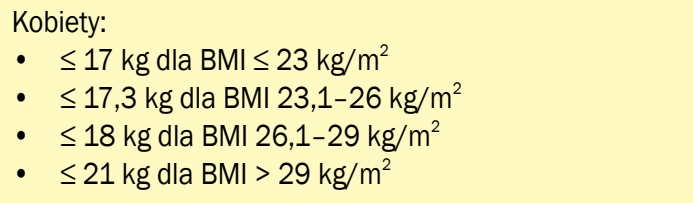 \\
\hline & 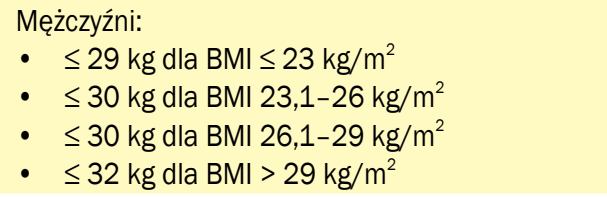 & 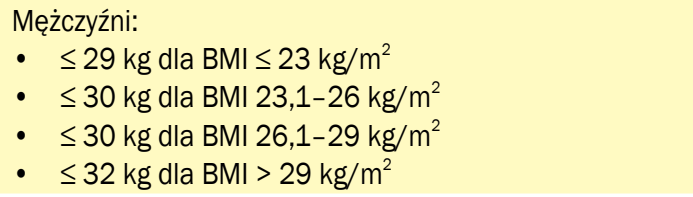 \\
\hline
\end{tabular}

*funt $=453,59 \mathrm{~g} ;$ CHS - Cardiovascular Health Study; WHAS - Women's Health and Aging Studies; BMI (body mass index) - wskaźnik masy ciała

W literaturze spotyka się różne definicje zespołu kruchości. Pierwsza z nich, ogólna, skupia się na deficytach w funkcjonowaniu poszczególnych układów związanych $z$ wiekiem. Diagnozę stawia się na podstawie wyliczonego wskaźnika - frailty index [2]. Druga definicja, powszechniejsza i prawdopodobnie powszechniej stosowana w codziennej praktyce, pozwala dokonać rozpoznania FS w przypadku występowania następujących objawów: niecelowej utraty masy ciała, zgłaszanego przez pacjenta ogólnego zmęczenia, słabości (mierzonej jako siła chwytu dłoni), zmniejszonej prędkości chodu i ograniczonej aktywności fizycznej [3]. Zespół kruchości można rozpoznać, jeśli u pacjenta występują co najmniej 3 z 5 wymienionych kryteriów. Niemniej różne grupy badaczy sformułowały odmienne kryteria definiujące poszczególne komponenty FS. Najczęściej stosowane definicje podsumowano w tabeli 1.

Co więcej, autorzy wysnuli podejrzenie, że przyczyną powyższych symptomów są przewlekłe zapalenie, zaburzenia 
hormonalne, sarkopenia oraz mała aktywność fizyczna, co skutkuje zmienionym metabolizmem i brakiem możliwości utrzymania homeostazy. Potwierdzają to wyniki badań, w których zaobserwowano zwiększone stężenie białka C reaktywnego, a obniżone - witaminy D oraz insulinopodobnego czynnika wzrostu 1 (IGF-1, insulin-like growth factor 1) u pacjentów z występującym opisywanym zespołem [4]. Do tej pory nie udało się jednak znaleźć jednego markera specyficznego dla FS.

Nie jest to rzadkie schorzenie i każdy praktykujący lekarz może się z nim spotkać. Częstość występowania FS waha się od 4\% do 59\% w grupie osób powyżej 65 . roku życia [5]. Ta rozpiętość jest spowodowana używaniem różnych definicji i brakiem standaryzacji poszczególnych kryteriów. Na podstawie kryteriów FS opracowanych przez CHS ogólna częstość występowania tego zespołu u osób starszych w wieku co najmniej 65 lat w Stanach Zjednoczonych wynosi 7-12\%. W badaniu CHS (Cardiovascular Health Study) częstość występowania FS zwiększa się z wiekiem od 3,9\% w grupie wiekowej 65-74 do 25\% w grupie wiekowej osób 85-letnich i starszych oraz jest większa u kobiet niż u mężczyzn (8\% v. 5\%) [3]. Częściej występuje także u osób rasy czarnej niż kaukaskiej (13\% v. 6\%). Podobne tendencje dotyczące wieku i różnice między płciami odnotowano w populacji osób dorosłych w krajach europejskich i latynoamerykańskich. W jednym z niedawnych badań przeprowadzonych wśród 7510 mieszkańców 10 krajów europejskich wykazano, że częstość występowania FS wynosiła od 5,8\% w Szwajcarii do $27 \%$ w Hiszpanii, ze średnią częstością występowania w całej Europie równą $17 \%$ [6]. Jak z tego wynika, FS w znacznym stopniu może się wiązać z różnicami w dostępie do opieki medycznej.

\section{Mechanizm występowania zespołu kruchości}

W warunkach fizjologicznych starzenie może być definiowane jako spadek i pogorszenie właściwości funkcjonalnych na poziomach komórkowym, tkankowym i narządowym. Ta utrata właściwości funkcjonalnych prowadzi do utraty homeostazy i zmniejsza zdolność adaptacji do stresu wewnętrznego i zewnętrznego, co powoduje zwiększoną podatność na choroby i śmiertelność. Starzenie to załamanie, utrzymywanych dotychczas na prawidłowym poziomie, struktur molekularnych i szlaków, utrata homeostazy [7]. Występuje duża zmienność osobnicza definiująca moment rozpoczęcia procesu starzenia, tempo, w jakim on postępuje oraz stopień, w jakim się rozwija. Różnice w przebiegu starzenia się odzwierciedlają różnice w zakresie zdolności funkcjonalnej. Zdolność funkcjonalna jest bezpośrednią miarą zdolności komórek, tkanek i narządów do prawidłowego/optymalnego działania pod wpływem zarówno genów, jak i środowiska. Optymalne działanie komórek, organów i organizmów odzwierciedla wydolność mechanizmów homeostazy. Mechanizmy te obejmują: naprawę DNA, jego syntezę i nadzór wierności zapisu; wykrywanie i usuwanie wadliwych białek i tłuszczów; usuwanie wadliwych organelli i komórek; obronę przed patogenami i urazami. Wiele fizjologicznych teorii starzenia się odnosi się do uszkodzenia wspomnianych mechanizmów konserwacyjnych (np. uszkodzenie DNA, wolne rodniki, mitochondrialne uszkodzenia i teorie immunoenzymetryczne).

Zespół kruchości nie jest tożsamy ze starzeniem się i może wystąpić zarówno znacznie później, jak i znacznie wcześniej niż naturalna starość. Zespół kruchości, czyli zespół geriatryczny charakteryzujący się osłabieniem, utratą masy ciała i małą aktywnością, która jest związana z niekorzystnymi skutkami zdrowotnymi, objawia się jako związana z wiekiem biologiczna podatność na stresory i zmniejszone rezerwy fizjologiczne, co powoduje ograniczoną zdolność do utrzymania homeostazy Jest to wynikiem złożonych zmian dotyczących wielu układów narządowych. Obserwuje się następujące zmiany markerów: podwyższone stężenia cytokin i chemokin, zmniejszone stężenia IGF-1, siarczanu dehydroepiandrosteronu (DHEAS, dehydroepiandrosterone sulfate) i leptyny, aktywację neutrofilów i monocytów, zaburzony rozkład krwinek białych. Ta definicja FS (dysregulacja wielu układów powodująca zmniejszenie rezerwy fizjologicznej i zwiększoną podatność na stresory) wykazuje podobieństwo do starzenia (utrata molekularnych/komórkowych właściwości funkcjonalnych, co prowadzi do zmniejszonej zdolności adaptacji do stresu wewnętrznego/zewnętrznego oraz zwiększonej podatności na choroby i śmiertelność). Obie sprowadzają się do utraty homeostazy, choć wraz ze starzeniem się zaburzenia są uogólnione, natomiast u pacjentów z kruchością niepowodzenia w cyklu homeodynamicznym dotyczą metabolizmu energetycznego i zmian nerwowo-mięśniowych. [8]. Rozwój FS na tle starości graficzne przedstawiono na rycinie 1.

\section{Związek zespołu kruchości z chorobowością}

Występowanie FS niesie za sobą poważne konsekwencje. Jest on czynnikiem ryzyka niepełnosprawności, hospitalizacji, upadków, a także zwiększonej śmiertelności. Rokowanie jest tym gorsze, im więcej kryteriów z definicji jest spełnionych lub im wyższy frailty index $[9,10]$. Dodatkowo występowanie tego zespołu zwiększa prawdopodobieństwo wystąpienia chorób układu sercowo-naczyniowego [11], które są obecnie główną przyczyną zgonów i hospitalizacji w całej Europie. Nie mniej istotny problem stanowią nowotwory u osób starszych. Przypuszcza się, że występowanie FS koreluje ze złą tolerancją chemioterapii. U pacjentów mocno schorowanych, obciążonych wieloma schorzeniami prawdopodobieństwo ujawnienia FS jest większe. Podobnie jest w przypadku osób czujących się samotnie, co ukazuje rolę, jaką może odegrać rodzina w procesie zdrowego 


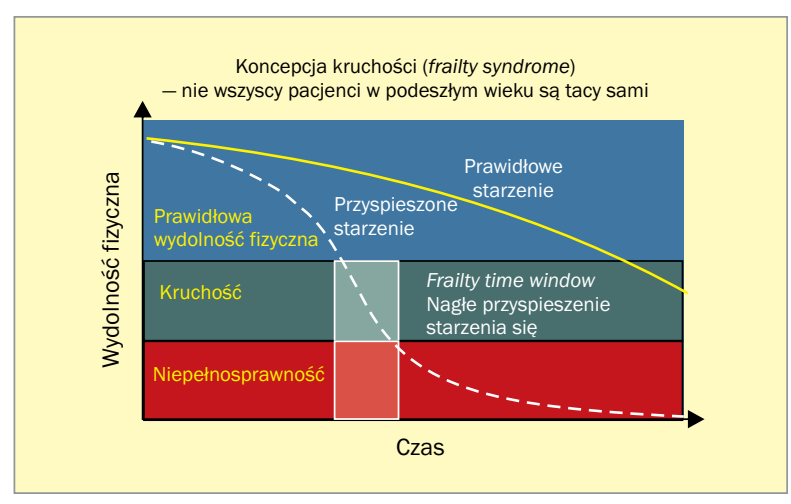

Rycina 1. Rozwój zespołu kruchości w czasie

starzenia. Osobom z FS trudniej jest stawić czoła codziennym obowiązkom i dlatego zazwyczaj potrzebuja pomocy w normalnym funkcjonowaniu. Nie każdy ma jednak dostęp do tego typu pomocy, co może stanowić problem nawet w przypadku tak błahych czynności, jak na przykład zakupy. Jednocześnie do stanów zwiastujących nadejście FS zaliczono również czynniki zewnętrzne, takie jak na przykład otyłość [12-15] (tab. 2, ryc. 2 [16]).

Niektórzy badacze postrzegają FS jako zespół chorobowy zwiastujący koniec życia pacjenta, ale badania wskazują, że kruchość nie jest procesem nieodwracalnym, co oczywiście jest nieuniknioną trajektorią zmierzająca do śmierci. Dlatego opracowanie i ocena interwencji służących zapobieganiu lub łagodzeniu słabości powinna pozostać jednym z głównych priorytetów w badaniach nad kruchością.

Istotne jest także, aby odnotować, że FS jest już na tyle istotnym problemem klinicznym, że jego występowanie oraz wpływ na rokowanie pacjentów odnotowano w opublikowanych w 2016 roku wytycznych Europejskiego Towarzystwa Kardiologicznego (ESC, European Society of Cardiology) [17]. W dokumencie tym zawarto wartości docelowe obowiązujące podczas ustalania celów leczenia wielu jednostek chorobowych. Podano, że w zależności od występowania FS należy modyfikować leczenie, między innymi nadciśnienia tętniczego i cukrzycy, a u pacjentów z FS wartości docelowe powinny być dobierane mniej rygorystycznie.

Co więcej, utrata masy mięśniowej jest bardziej intensywna u kobiet w związku ze zmianami stężeń estrogenów po menopauzie. Może to być uzasadnieniem częstszego występowania FS wśród kobiet. Kolejnym czynnikiem sprzyjającym niepożądanym zmianom w mięśniach jest powszechny w klimacie umiarkowanym niedobór witaminy D. Powoduje to osłabienie mięśni antygrawitacyjnych i w konsekwencji upadki [18], co wskazuje na zasadność stałej suplementacji witaminy D. Nie ulega wątpliwości, że najlepszym sposobem na radzenie sobie z powyższymi zmianami w mięśniach jest regularna aktywność fizyczna.
Tabela 2. Różnice w pozostałej szacowanej długości życia w populacji ogólnej i w grupie osób z zespołem kruchości (FS, frailty syndrome) (na podstawie [8])

\begin{tabular}{|ccc|}
\hline $\begin{array}{l}\text { Wiek } \\
\text { (lata) }\end{array}$ & $\begin{array}{c}\text { Pozostała szacowana } \\
\text { długość życia populacji } \\
\text { ogólnej (lata) }\end{array}$ & $\begin{array}{c}\text { Różnica u osób z FS } \\
\text { (wg definicji fenotypowej) } \\
\text { (lata) }\end{array}$ \\
\hline 65 & 18,4 & $-1,1$ \\
70 & 14,9 & $-1,0$ \\
75 & 11,7 & $-0,9$ \\
80 & 8,9 & $-0,7$ \\
85 & 6,5 & $-0,6$ \\
90 & 4,6 & $-0,4$ \\
95 & 2,8 & $-0,2$ \\
100 & 0,4 & $-0,2$ \\
\hline
\end{tabular}

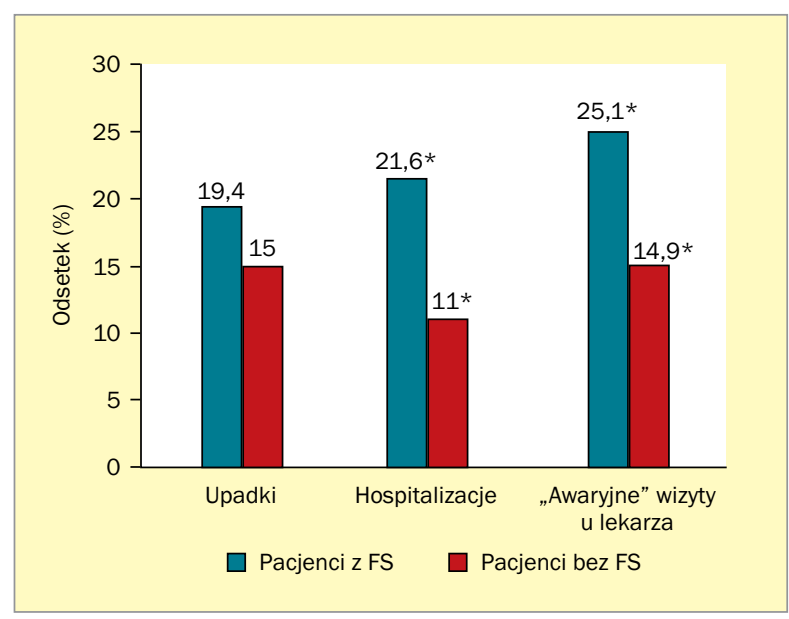

Rycina 2. Zdarzenia w populacji osób w podeszłym wieku w okresie 6 miesięcy; ${ }^{*} \mathrm{p}<0,05$ (na podstawie [16])

Dzięki niej nie tylko zostaje zatrzymywana utrata mięśni, ale masa mięśniowa może nawet wzrosnąć, a - co za tym idzie - zwiększy się również ich siła. Wpływa to na codzienne funkcjonowanie, zmienia rokowanie i odwleka FS [19]. Odpowiednie ćwiczenia i środki ostrożności przedsięwzięte w domu mogą zapobiec zmniejszonej aktywności fizycznej oraz zmniejszyć liczbę upadków [20].

\section{Zapobieganie zespołowi kruchości i jego leczenie}

Zapobieganie FS i leczenie tego zespołu jest możliwe, zależy jednak od wczesnego wykrycia choroby. Sposób pomocy musi zostać dobrany indywidualnie w zależności od przyczyny. Leczenie powinno być długoterminowe, najlepiej dożywotnie. Celem terapii jest poprawa stanu 
fizycznego i psychicznego oraz jak najdłuższe utrzymanie aktywności społecznej i samodzielnego funkcjonowania [21]. Ważne są również wsparcie i zachęta do podążania zaplanowanym tokiem terapeutycznym, ponieważ - jak wskazują badania - pacjenci prawidłowo wykonujący zalecenia lekarskie cieszą się lepszym zdrowiem [22]. Na uwage zasługują również pacjenci, u których występują objawy typowe dla FS, ale ich liczba nie pozwala rozpoznać tego zespołu. Takie osoby powinny zostać poddane podobnej opiece, by zapobiec ujawnieniu kolejnym symptomów.

Wspomniana wcześniej utrata masy ciała może być związana zarówno z utratą masy mięśniowej, jak i kostnej. Po 40. roku życiu rozpoczyna się atrofia mięśni. Najpierw 8\% masy mięśniowej co dekadę, a po 70. roku życia następuje akceleracja do straty 15\% masy mięśniowej co dekadę [13]. Uzasadnieniem dla tego zjawiska jest udokumentowana przewaga procesów katabolicznych nad anabolicznymi u osób starszych [14]. Odżywianie jest czynnikiem ściśle związanym z FS [23]. Powszechnie zaakceptowane kryteria kruchości dotyczące słabości, niezamierzonej utraty masy ciała, niskiej siły mięśni, uczucia wyczerpania, zmniejszenia aktywności fizycznej i powolnego tempa poruszania się są mniej lub bardziej powiązane ze złymi nawykami żywieniowymi. Z jednej strony przewlekłe niedożywienie, niewystarczające spożycie białka i energii prowadzą do utraty masy ciała i sarkopenii, co z kolei może powodować niską siłę mięśni i uczucie wyczerpania. Z drugiej strony słabość może negatywnie wpływać na sam proces przyjmowania pokarmów, a tym samym - na stan odżywienia. W pewnym sensie złe nawyki żywieniowe i kruchość są ze sobą powiązane.
Opisany wyżej proces może być przyspieszony przez niedostateczne spożycie białka, które również charakteryzuje proces starzenia. Anoreksja starcza, tj. utrata apetytu, powoduje zmniejszenie spożycia pokarmów i przyczynia się do niewystarczającego spożycia białka. Poza tym osoby starsze unikają spożywania białka zwierzęcego ze względu na czynniki związane ze starzeniem się, głównie trudności z żuciem, zmiany smaku i zapachu oraz problemy zdrowotne związane z przyjmowaniem cholesterolu i tłuszczu nasyconego. Jednak nawet jeśli spożycie białka jest wystarczające, to istnieje wiele czynników związanych z wiekiem (oporność na insulinę, zaburzenia trawienia białka i wchłanianie aminokwasów), które mogą hamować stymulację syntezy białek mięśniowych u osób starszych. Ta niska synteza białek mięśniowych w połączeniu z wysoką częstością rozpadu obserwowaną u osób starszych powoduje ujemny bilans białka mięśniowego i wpływa negatywnie na masę mięśni szkieletowych [23].

Osłabione spożycie pokarmów może powodować niedobory mikroelementów, które mogłyby się przyczynić do rozwoju kruchości. Witamina $\mathrm{D}$ i wapń są bardzo istotne, ponieważ mogą wpływać na zdrowie kości, a - co za tym idzie - na mobilność. Niewystarczające spożycie zarówno wapnia, jak i witaminy D obserwowano w populacji osób starszych i może przyspieszyć resorpcję kości obserwowaną u osób starszych. Dodatkowo izolacja społeczna, wynikająca z depresji lub pogorszenia ogólnego stanu zdrowia, może zmniejszyć ekspozycję na działanie promieni słonecznych, a tym samym produkcję witaminy D w skórze lub wysiłek fizyczny, co jest głównym czynnikiem stymulującym utrzymanie homeostazy kości. Należy zauważyć,

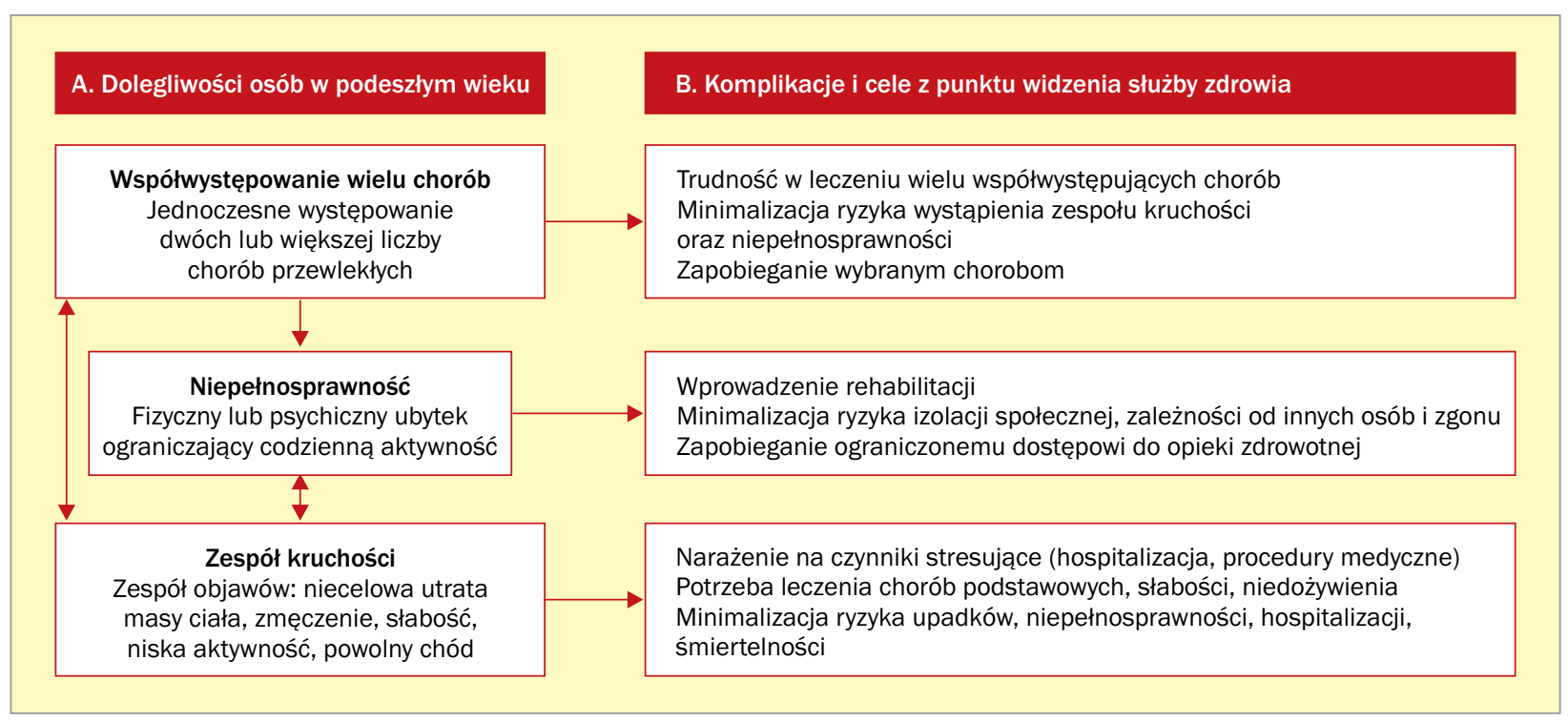

Rycina 3. Współwystępowanie wielu chorób, niepełnosprawność, zespół kruchości; komplikacje i cele z punktu widzenia służby zdrowia (na podstawie [26]) 
że w przypadku mikroskładników pokarmowych spożycie pokarmów niekoniecznie odzwierciedla stan odżywienia w organizmie, szczególnie u osób w podeszłym wieku. Podsumowując, obserwacje te sugerują, że w populacji osób starszych zmniejszone spożycie pokarmów, w połączeniu z przemianami metabolizmu wapnia i witaminy D, oraz czynniki genetyczne mogą predysponować do pojawienia się FS.

Mimo obiecujących prób zastosowania metforminy u myszy [24, 25] jako „leku na długowieczność” obecnie nie ma leku, który mógłby w istotny sposób zapobiec wystąpieniu FS. Pozostaje eliminowanie poszczególnych schorzeń, tak aby do FS nie dopuścić lub skutecznie go leczyć. Szacuje się, że 3-5\% zgonów można by odwlec w czasie, gdyby zapobiec FS [7]. Natomiast brak FS jest wyznacznikiem zdrowego starzenia [26]. Dlatego obecnie podstawą leczenia pacjentów z FS lub obciążonych czynnikami jego wystąpienia jest nie tylko leczenie chorób współistniejących, ale także poradnictwo i suplementacja dietetyczna, mogące w istotny sposób poprawić ogólny stan leczonych pacjentów.

\section{Podsumowanie}

Zespół kruchości jest powszechnie występującą dolegliwością u osób po 65. roku życia. Prowadzi do niego brak możliwości utrzymania homeostazy w podeszłym wieku. Jest on obarczony złym rokowaniem oraz wiąże się z pogorszeniem jakości życia chorego. Jego częstość wzrasta z wiekiem. Leczenie FS wymaga holistycznego podejścia do pacjenta i kompleksowej, długoterminowej opieki. Kliniczna ocena obecności FS pozwala na ustalenie dalszego postępowania oraz informuje o stanie zdrowia starszych pacjentów (ryc. 3) [26].

\section{Konflikt interesów}

Autorzy deklarują brak konfliktu interesów.

\section{Abstract}

The aging process does not occur in the same way for all patients. The pace of this process, both physical and mental, is very different. The quality of life of an elderly patient depends on many factors, including lifestyle, genetic predisposition and appropriate medical care. The quality of health care depends, among other things, on how quickly and, whether or not, the doctor sees correctly signs of premature or „abnormal” aging. To facilitate this, a set of symptoms was identified, the occurrence of which should alert the doctor due to the relationship with increased mortality. In the English-language literature, this group is called frailty syndrome. In the Polish literature, the most widely used description of this phenomenon is probably zespół kruchości. The aim of this paper was to present the importance of this syndrome in clinical practice.

Key words: aging, fragility syndrome, old age

Folia Cardiologica 2018; 13, 2: 137-143

\section{Piśmiennictwo}

1. Prognoza ludności na lata 2014-2050. Studia i Analizy Statystyczne. GUS, Warszawa 2014.

2. Searle SD, Mitnitski A, Gahbauer EA, et al. A standard procedure for creating a frailty index. BMC Geriatr. 2008; 8: 24, doi: 10.1186/14712318-8-24, indexed in Pubmed: 18826625.

3. Fried LP, Tangen CM, Walston J, et al. Cardiovascular Health Study Collaborative Research Group. Frailty in older adults: evidence for a phenotype. J Gerontol A Biol Sci Med Sci. 2001; 56(3): M146-M156, indexed in Pubmed: 11253156.

4. Walston J, Hadley EC, Ferrucci L, et al. Research agenda for frailty in older adults: toward a better understanding of physiology and etiology: summary from the American Geriatrics Society/National Institute on Aging Research Conference on Frailty in Older Adults. J Am Geriatr Soc. 2006; 54(6): 991-1001, doi: 10.1111/j.1532-5415.2006.00745.x, indexed in Pubmed: 16776798.
5. Collard RM, Boter H, Schoevers RA, et al. Prevalence of frailty in community-dwelling older persons: a systematic review. J Am Geriatr Soc. 2012; 60(8): 1487-1492, doi: 10.1111/j.1532-5415.2012.04054.x, indexed in Pubmed: 22881367.

6. Santos-Eggimann B, Cuénoud P, Spagnoli J, et al. Prevalence of frailty in middle-aged and older community-dwelling Europeans living in 10 countries. J Gerontol A Biol Sci Med Sci. 2009; 64(6): 675-681, doi: 10.1093/gerona/glp012, indexed in Pubmed: 19276189.

7. Veronese N, Cereda E, Stubbs B, et al. Risk of cardiovascular disease morbidity and mortality in frail and pre-frail older adults: Results from a meta-analysis and exploratory meta-regression analysis. Ageing Res Rev. 2017; 35: 63-73, doi: 10.1016/j.arr.2017.01.003, indexed in Pubmed: 28143778.

8. Balducci L. Aging, frailty, and chemotherapy. Cancer Control. 2007; 14(1): $7-12$, doi: $10.1177 / 107327480701400102$, indexed in Pubmed: 17242666 . 
9. Ensrud KE, Ewing SK, Cawthon PM, et al. Osteoporotic Fractures in Men Research Group. A comparison of frailty indexes for the prediction of falls, disability, fractures, and mortality in older men. J Am Geriatr Soc. 2009; 57(3): 492-498, doi: 10.1111/j.1532-5415.2009.02137.x, indexed in Pubmed: 19245414.

10. Shamliyan T, Talley KMC, Ramakrishnan R, et al. Association of frailty with survival: a systematic literature review. Ageing Res Rev. 2013; 12(2): 719-736, doi: 10.1016/j.arr.2012.03.001, indexed in Pubmed: 22426304.

11. Cheng H, Gurland BJ, Maurer MS. Self-reported lack of energy (anergia) among elders in a multiethnic community. J Gerontol A Biol Sci Med Sci. 2008; 63(7): 707-714, indexed in Pubmed: 18693225.

12. TopinkováE. Aging, disability and frailty. Ann Nutr Metab. 2008; 52 (Suppl1): 6-11, doi: 10.1159/000115340, indexed in Pubmed: 18382070.

13. Kim TN, Choi KM. Sarcopenia: definition, epidemiology, and pathophysiology. J Bone Metab. 2013; 20(1): 1-10, doi: 10.11005/ /jbm.2013.20.1.1, indexed in Pubmed: 24524049.

14. Ebner N, Sliziuk V, Scherbakov N, et al. Muscle wasting in ageing and chronic illness. ESC Heart Fail. 2015; 2(2): 58-68, doi: 10.1002/ /ehf2.12033, indexed in Pubmed: 28834653.

15. Sirola J, Kröger H. Similarities in acquired factors related to postmenopausal osteoporosis and sarcopenia. J Osteoporos. 2011; 2011: 536735, doi: 10.4061/2011/536735, indexed in Pubmed: 21904688.

16. González-Vaca J, de la Rica-Escuín M, Silva-lglesias M, et al. Frailty in INstitutionalized older adults from ALbacete. The FINAL Study: rationale, design, methodology, prevalence and attributes. Maturitas. 2014; 77(1): 78-84, doi: 10.1016/j.maturitas.2013.10.005, indexed in Pubmed: 24189222.

17. Piepoli MF, Hoes AW, Agewall S, et al. ESC Scientific Document Group. 2016 European Guidelines on cardiovascular disease prevention in clinical practice: the Sixth Joint Task Force of the European Society of Cardiology and Other Societies on Cardiovascular Disease Prevention in Clinical Practice (constituted by representatives of 10 societies and by invited experts)Developed with the special contribution of the European Association for Cardiovascular Prevention \& Rehabilitation (EACPR). Eur Heart J. 2016; 37(29): 2315-2381, doi: 10.1093/eurheartj/ehw106, indexed in Pubmed: 27222591.

18. Czerwiński E, Kumorek A. Upadki, witamina D i złamania. Post Nauk Med. 2012; 25: 226-231.

19. Phu S, Boersma D, Duque G. Exercise and sarcopenia. J Clin Densitom. 2015; 18(4): 488-492, doi: 10.1016/j.jocd.2015.04.011, indexed in Pubmed: 26071171.

20. Gillespie LD, Robertson MC, Gillespie WJ, et al. Interventions for preventing falls in older people living in the community. Cochrane Database Syst Rev. 2009(2): CD007146, doi: 10.1002/14651858. CD007146.pub2, indexed in Pubmed: 19370674.

21. Fairhall N, Langron C, Sherrington C, et al. Treating frailty - a practical guide. BMC Med. 2011; 9: 83, doi: 10.1186/1741-7015-9-83, indexed in Pubmed: 21733149.

22. DiMatteo MR, Giordani PJ, Lepper HS, et al. Patient adherence and medical treatment outcomes: a meta-analysis. Med Care. 2002; 40(9): 794-811, doi: 10.1097/01.MLR.0000024612.61915.2D, indexed in Pubmed: 12218770.

23. Yannakoulia M, Ntanasi E, Anastasiou CA, et al. Frailty and nutrition: from epidemiological and clinical evidence to potential mechanisms. Metabolism. 2017; 68: 64-76, doi: 10.1016/j.metabol.2016.12.005, indexed in Pubmed: 28183454.

24. Martin-Montalvo A, Mercken EM, Mitchell SJ, et al. Metformin improves healthspan and lifespan in mice. Nat Commun. 2013; 4: 2192, doi: 10.1038/ncomms3192, indexed in Pubmed: 23900241.

25. Kaeberlein M, Kennedy BK. Ageing: a midlife longevity drug? Nature. 2009; 460(7253): 331-332, doi: 10.1038/460331a, indexed in Pubmed: 19606132.

26. Fried LP, Ferrucci L, Darer J, et al. Untangling the concepts of disability, frailty, and comorbidity: implications for improved targeting and care. J Gerontol A Biol Sci Med Sci. 2004; 59(3): 255-263, indexed in Pubmed: 15031310. 